\title{
Analyzing The Formulation of Business Strategy of Pelita Kita Trading Company
}

\author{
Susriyanti ${ }^{1}$, Fitri Yeni ${ }^{2}$, Riche Fermayani ${ }^{3}$, Erwin H Harahap ${ }^{4}$ \\ ${ }^{I}$ UPI YPTK Padang FEB Management Departement, Indonesia \\ ${ }^{2}$ UPI YPTK Padang FEB Management Departement, Indonesia \\ ${ }^{3}$ STIE Perbankan Indonesia Padang Management Departement, Indonesia \\ ${ }^{4}$ UPI YPTK Padang FEB Management Departement, Indonesia \\ susriyanti@upiyptk.ac.id
}

\begin{abstract}
Abstrak-UD. Pelita Kita adalah sebuah perusahaan dagang yang menjual kayu, kunsen jendela, pintu, panel, dan aneka jenis ukuran olahan kayu yang dibelah maupun diketam. Tujuan penulisan penelitian ini adalah untuk melakukan analisis internal maupun eksternal perusahaan agar dapat menyusun formulasi strategi bisnis perusahaan dalam menciptakan keunggulan kompetitif dengan perusahaanperusahaan sejenis yang bergerak dalam bidang yang sama. Teknik pengumpulan data dengan wawancara, survey dan kuisioner. Metode penelitian merupakan studi kasus menggunakan metode deskriptif kualitatif. Data-data yang telah diperoleh akan dianalisis menggunakan Matriks IFE, EFE, CPM, TOWS, dan IE, SPACE. Hasil matriks IFE sebesar 2,795 dan matriks EFE sebesar 2,921. Hasil analisis Matriks TOWS, SPACE, IE, Grand Strategy menunjukkan alternatif strategi yang dapat diterapkan oleh perusahaan dalam berkompetisi yaitu strategi penetrasi pasar (market penetration) dan pengembangan pasar (market development). Dari Matriks QSPM strategi yang paling dianjurkan untuk dilakukan perusahaan adalah strategi penetrasi pasar (market penetration) karena memiliki total nilai daya tarik yang lebih besar dibandingkan dengan strategi lainnya.
\end{abstract}

Kata kunci: manajemen strategi, analisis SWOT, pengembangan pasar, pengembangan produk

Abstract-Pelita Kita is a trading company that sells woods, windows frame, doors, panels and various types of processed woods. Using environmental analysis, the present study seeks to examine the formulation of business strategy as an effort to create a competitive advantage. Data were collected through interviews and questionnaires and then analyzed using the following matrices: IFE, EFE, CPM, TOWS, IE, and SPACE. The results of analysis revealed that the studied company may employ some alternative strategies such as market penetration and market development to compete. It is also concluded that market penetration is more preferable because it has a greater total value of attraction compared to other strategies.

Keyword: strategy management, SWOT analysis, market development, product development

\section{PENDAHULUAN}

Perdagangan kayu di Padang Sumatera Barat cukup berkembang pesat saat ini dengan jumlah pemain yang semakin bertambah dari waktu ke waktu. Dengan perkembangan yang terjadi tentulah perusahaan yang bergelut dalam bidang ini harus mampu bersaing untuk tetap bertahan hidup dalam persaingan pasar yang terus bertumbuh. "Dalam era revolusi industri, keunggulan daya saing suatu entitas usaha ditentukan oleh efisiensi dalam alokasi sumber daya atau aset berwujud (tangible resources/assets) yang mudah dijabarkan dalam dimensi keuangan. Sebaliknya, dalam era revolusi informasi, keunggulan daya saing suatu entitas usaha sangat tergantung pada kemampuannya untuk memobilisasi dan mengeksploitasi sumber daya atau aset tak berwujud (intangible resources/asssets) yang tidak mudah dijabarkan dalam dimensi keuangan" (Prakarsa dalam Yuwono, 2007).

Kayu merupakan suatu komoditas produk nature yang tidak bisa ditiru. Jadi kualitas produk yang dijual perusahaan akan sangat bergantung dari kualitas kayu yang dihasilkan oleh alam. Dalam usaha ini pengetahuan pedagang tentang kualitas kayu sangatlah penting terutama dalam proses pensortiran. Karena kualitas yang dilihat dari produk berwujud ditentukan oleh alam, maka differensiasi produk akan sangat sulit diciptakan (cenderung seragam). Maka dalam usaha dagang ini perusahaan akan lebih banyak menggunakan aset tak berwujud sebagai alat untuk menciptakan keunggulan bersaing.

Untuk itu para pelaku usaha perlu mengenali berbagai unsur dasar guna mencapai keunggulan bersaing tersebut. UD. Pelita Kita merupakan sebuah perusahaan dagang yang telah dirintis sejak tahun 1970-an dan saat ini beralamat di Jalan Ampalu Raya No. 20 di by. Pass km 5 arah ke pelabuhan Teluk Bayur Padang. Dan tepat pula berada di persimpangan perumnas Pegambiran, perumnas Emilindo, dan perumnas Pegambiran Permai. Posisi letak UD. Pelita Kita cukup strategis dan sangat mudah dijangkau oleh konsumennya. Konsumen UD. Pelita Kita berasal dari sekitar wilayah kota Padang dan luar kota Padang. Dalam rentang waktu yang sangat lama yaitu lebih kurang 49 tahun UD. Pelita Kita telah membuktikan diri masih tetap dapat bertahan hidup dalam 
lingkungan bisnis ini di kota Padang. Hal ini tentu saja tidak terlepas dari kemampuan kompetensi yang dimiliki oleh pemilik usaha selama ini. Ketatnya persaingan bisnis yang makin terasa dengan banyaknya bermunculan pemain-pemain baru dalam bisnis ini menuntut perusahaan untuk dapat menciptakan keunggulan-keunggulan kompetitif melalui perumusan strategi yang memungkinkan perusahaan agar dapat bertahan, terus tumbuh dan berkembang di masa yang akan datang.

Penerapan manajemen strategis yang baik diawali dengan formulasi, yaitu proses pembuatan visi dan misi, mengenali ancaman dan peluang suatu organisasi, menentukan kekuatan dan kelemahan suatu organisasi, membangun tujuan jangka panjang, merumuskan alternatif strategi, dan memilih strategi tertentu yang akan dilaksanakan. Setelah formulasi ditetapkan, berikutnya perusahaan harus mengimplementasikan formulasi strategi manajemen tersebut ke dalam proses bisnis perusahaan. Setelah strategi manajemen diimplementasikan, maka perusahaan harus mengevaluasi hasil implementasi formulasi strategi manajemen tersebut, apakah sudah sesuai untuk diterapkan dalam proses bisnis perusahaan atau tidak. Apabila sesuai, tentu saja strategi manajemen akan dapat meningkatkan hasil kinerja perusahaan, begitu juga sebaliknya.

Kuncoro (2010) dalam penelitiannya yang berjudul "Analisis Perumusan Strategi Bisnis Pada PT. Samudera Nusantara Logistindo" mendapatkan 2,885 untuk matrik IFE dan 2,623 untuk matrik EFE dengan hasil analisis matrik TOWS, SPACE, IE dan Grand Straegy. Hasil yang didapat menunjukkan alternatif strategi yang dapat digunakan perusahaan adalah strategi penetrasi pasar dan pengembangan produk. Adapun kata kunci yang digunakan dalam penelitian ini adalah manajemen strategi, matrik SWOT, pengembangan pasar, dan pengembangan produk.

Sementara itu Tafti, et all (2013) dalam penelitian lainnya berjudul "Asssessment and Analysis Strategies According to Space Matrix-Case Study: Petrocemical and Banking Industries in Tehran Stock Exchange (TSE)" mendapatkan hasil untuk mendukung perusahaan melakukan strategi agresif dalam menghadapi persaingan pasar dalam industri ini. Adapun kata kunci yang digunakan dalam penelitian ini adalah strategic planning, strategic formulation tool, space matrix, sanction.

Pengembangan perusahaan melalui manajemen strategi yang baik sangat penting agar perusahaan dapat mengevaluasi kinerja keseluruhan perusahaan secara berkala sehingga dapat diketahui faktor-faktor apa yang menghambat kemajuan perusahaan dan dapat dicari penanggulangannya. Dan juga berguna untuk mencari faktor-faktor apa sajayang menjadi kekuatan perusahaan agar dapat dikembangkan bagi keuntungan dan kekuatan bersaing perusahaan di industri ini. Persaingan yang semakin ketat dan tajam, menyebabkan banyak perusahaan jatuh bangkrut karena kalah bersaing. Kondisi ini mengharuskan perusahaan untuk memiliki daya saing yang tinggi agar dapat menjadi perusahaan yang makin kuat, tetap dapat bersaing dengan perusahaan sejenis dan bisa menjadi yang terbaik diantara perusahaan lainnya.

Berdasarkan uraian di atas maka dapatlah penulis membuat perumusan masalah dalam penulisan ini. Adapun identifikasi masalah yang dapat dirumuskan adalah:

1. Bagaimana mengidentifikasi faktor internal (kekuatan dan kelemahan) dan faktor eksternal (peluang dan ancaman) pada UD. Pelita Kita.

2. Bagaimana memformulasikan strategi bisnis untuk UD. Pelita Kita dalam meningkatkan daya saing perusahaan.

Sedangkan tujuan penelitian ini adalah untuk menjawab perumusan masalah di atas. Selanjutnya diharapkan dari hasil pembahasan penelitian ini penulis dapat memberi usulan atau rekomendasi strategi bisnis yang digunakan perusahaan. Hasil kajian diharapkan dapat menjadi tolak ukur atau pijakan untuk menyusun perencanaan yang baik di masa yang akan datang dan merupakan suatu analisis yang efektif bagi perkembangan perusahaan serta dapat dijadikan sebagai masukan konstruktif untuk pedoman penyusunan strategi perusahaan berikutnya.

\section{KAJIAN PUSTAKA}

Pola pikir manajemen dalam mengelola perusaan saat ini dituntut semakin berkembang. Tidak cukup pada pola pikir manajemen situasional atau pola pikir kontingensi semata yang cenderung memperhatikan kondisi situasi saja. Tapi pola pikir manajemen makin berkembang ke manajemen fleksibel untuk menghindari kekakuan (reginitas) manajemen. Pencapaian efesiensi dan efektifitas yang dilakukan oleh manajer yang berkarakter, tidak menyimpang jauh dari konsep dan objek yang telah ditentukan. Pemimpin perusahaan harus memahami betul-betul bisnisnya sehingga dapat mengetahui strategi yang harus dibuat dalam menghadapi perubahan dan situasi tertentu. "Strategi adalah suatu 
alat untuk mencapai tujuan jangka panjang" (David, 2009). Dalam perumusan strategi, faktor-faktor yang harus dipertimbangkan adalah kondisi internal (kekuatan dan kelemahan) dan kondisi eksternal (peluang dan ancaman) yang dihadapi perusahaan. Hansen dan Smith (David, 2006) pernah menjelaskan bahwa "perencanaan strategi melibatkan pilihan yang membahayakan sumber daya dan trade-off yang mengorbakan peluang, artinya dalam menetapkan strategi menanggung resiko yang besar sehingga membutuhkan keputusan manajemen tingkat atas prioritas harus ditetapkan".

Menurut David (2009), "proses manajemen strategis terdiri dari tiga tahap, yaitu perumusan strategi (strategic formulation), implementasi strategi (strategic formulation), dan evaluasi strategi (strategic evaluation). Perumusan strategi termasuk mengembangkan misi bisnis, mengenali peluang dan ancaman eksternal perusahaan, menetapkan kekuatan dan kelemahan internal perusahaan, menetapkan tujuan jangka panjang, menghasilkan strategi alternatif, dan memilih strategi tertentu yang akan dilaksanakan. Implementasi strategi menuntut perusahaan menetapkan obyektif tahunan, memperlengkapi dengan kebijakan, memotivasi karyawan, dan mengalokasikan sumber daya sehingga strategi yang dirumuskan dapat dilaksanakan; implementasi strategi termasuk mengembangkan budaya mendukung strategi, menciptakan struktur organisasi yang efektif, mengubah arah usaha pemasaran, menyiapkan anggaran, mengembangkan dan memanfaatkan sistem informasi, dan menghubungkan kompensasi karyawan dengan prestasi organisasi”. Evaluasi strategi adalah tahap akhir dalam manajemen strategis. Para pemimpin perusahaan/organisasi sangat perlu mengetahui kapan strategi tertentu tidak berfungsi dengan baik.

Analisis lingkungan eksternal (peluang dan ancaman) menurut Hit (2001) "menjabarkan bahwa; Pertama, peluang (opportunities) adalah kondisikonsisi dalam lingkungan umum yang dapat membantu organisasi mencapai daya saingnya. Ke dua, ancaman (threats) adalah kondisi-kondisi dalam lingkungan umum yang dapat mengganggu usaha organisasi dalam mencapai daya saing strategis. Tujuan audit eksternal adalah untuk mengembangkan daftar terbatas peluang yang dapat dimanfaatkan oleh organisasi dan ancaman yang harus dihindari.
Komponen analisis eksternal terdiri dari: scanning, mengidentifikasi petunjuk awal dari perubahan dan kecenderungan lingkungan; monitoring, mendeteksi arti melalui observasi terus menerus atas perubahan dan kecenderungan lingkungan; forecasting, mengembangkan proyeksi atas hasil yang diantisipasi berdasarkan perubahan dan kecenderungan yang dimonitor; assessing, menentukan waktu dan pentingnya perubahan serta kecenderungan lingkungan untuk strategi organisasi dan manajemennya. Selanjutnya analisis lingkungan internal (kekuatan dan kelemahan), terdiri dari: kekuatan (strenghts)yakni sumber daya, keterampilan atau keunggulan-keunggulan lain relatif terhadap pesaing dan kebutuhan masyarakat yang dilayani atau ingin dilayani oleh organisasi; kelemahan (weakness) yakni keterbatasan atau kekurangan dalam sumder daya, keterampilan dan kapabilitas yang secara serius menghambat kinerja efektif organisasi”.

Untuk membangun keunggulan kompetitif berkelanjutan, menurut Walker (2007) yang harus dilakukan oleh organisasi adalah dengan mengoptimalkan resources capabilities, yang terdir dari value drivers, cost drivers, retaining costumers, dan preventing imitation. Value drivers dan cost drivers akan menciptakan posisi pasar yang kuat (superior market position), sedangkan retaining costumers (mempertahankan konsumen) dan preventing imitation (mencegah imitasi produk) akan mendorong posisi pasar yang mampu bertahan (defendable market position). Jika kedua variabel ini (superior market position dan defendable market position) mampu dipertahankan oleh organisasi maka pada gilirannya akan dapat mewujudkan keunggulan kompetitif berkelanjutan (sustainable competitive advantage).

Menurut David (2006), teknik perumusan strategi yang penting dapat diintegrasikan ke dalam kerangka kerja pengambilan keputusan tiga tahap yang terdiri dari tahap input, tahap pencocokan, dan tahap keputusan. Tahap pertama, yaitutahap input meringkas informasi dasar yang dibutuhkan untuk merumuskan strategi. Tahap kedua, yaitu tahap pencocokkan faktor eksternal dan internal kunci. Tahap ketiga, yaitu tahap keputusan untuk mengevaluasi secara objektif alternatif-alternatif strategi yang layak dan dengan demikian, memberikan dasar tujuan untuk memilih strategi yang spesifik. 


\section{METODE PENELITIAN}

Metode deskriptif kualitatif adalah metode penelitian yang digunakan yaitu suatu metode yang bertujuan membantu memecahkan masalah yang terjadi pada masa sekarang serta berpusat pada masalah aktual. Metode ini dapat memberikan gambaran tentang kondisi, keadaan, maupun sifat dari sesuatu yang sedang terjadi pada saat penelitian sedang dilakukan. Dan untuk merumuskan atau memformulasikan strategi, terdiri dari tiga tahap. Pertama, tahap masukan dengan menggunakan matriks Evaluasi Faktor Ekternal (External Factor Evaluation/EFE) dan matriks Evaluasi Faktor Internal (Internal Factor Evaluation/IFE). Ke dua, tahap pencocokkan menggunakan matriks TOWS (Treats, Opportunities, Weakness, Strenght) dan matriks Internal-Eksternal/IE. Ke tiga, tahap keputusan dengan menggunakan matriks QSPM (Quantitative strategic Planning Matrix).

Penyusunan matriks IFE diperoleh dari hasil evaluasi fakor-faktor internal perusahaan, sedangakan matriks EFE diperoleh dari hasil evaluasi fakor-faktor eksternal perusahaan. Nilai bobot diperoleh dari perhitungan menggunakan AHP (Analitytic Hierarchi Process), dengan dukungan program excel yang dilakukan setelah diketahui skala prioritas antar elemen-elemen faktor yang ada melalui pengisian kuisioner yang diberikan kepada pemilik perusahaan. Untuk nilai peringkat juga ditentukan berdasarkan informasi dari hasil pengisian kuisioner kepada pemilik perusahaan. Dari hasil perhitungan bobot dan peringkat, maka akan diperoleh suatu nilai yang kemudian keseluruhan nilai akan dijumlahkan.

\section{HASIL DAN PEMBAHASAN}

Hasil analisis terhadap faktor internal perusahaan, yaitu kekuatan (strenght) dan kelemahan (weakness) dan faktor eksternal yang meliputi peluang (opportunity) dan ancaman (threat) disajikan pada tebel 2 dan 3 di bawah ini:

Tabel 1 Faktor-faktor Internal Kunci UD. Pelita Kita

\begin{tabular}{|c|c|}
\hline Faktor-faktor Internal Kunci & Skor \\
\hline \multicolumn{2}{|l|}{ Kekuatan: } \\
\hline 1. Sudah dipercaya konsumen karena merupakan & 4 \\
\hline $\begin{array}{l}\text { penjual kayu yang sudah lama ada. } \\
\text { 2. Kualitas produk selalu dijaga dengan baik }\end{array}$ & 3 \\
\hline $\begin{array}{l}\text { 3. Penjualan produk berkembang ke jasa } \\
\text { pengolahan kayu berupa pembuatan pintu, } \\
\text { jendela, kusen, dll }\end{array}$ & 2 \\
\hline $\begin{array}{l}\text { 4. Terletak di lokasi yang mudah dijangkau oleh } \\
\text { konsumen }\end{array}$ & 2 \\
\hline $\begin{array}{l}\text { 5. Mempunyai supplier-supplier yang loyal dan } \\
\text { dipercaya }\end{array}$ & 3 \\
\hline \multicolumn{2}{|l|}{ Kelemahan: } \\
\hline $\begin{array}{l}\text { 1. Keterbatasan dana dalam pengambilan kayu } \\
\text { dari suppplier }\end{array}$ & 1 \\
\hline $\begin{array}{l}\text { 2. Keterbatasan mesin yang masih kurang } \\
\text { memadai }\end{array}$ & 2 \\
\hline $\begin{array}{l}\text { 3. Kurangnya karyawan yang berkualitas tentang } \\
\text { perkayuan }\end{array}$ & 2 \\
\hline $\begin{array}{l}\text { 4. Manajemen sistem yang masih tradisional } \\
\text { (manajemen lama) }\end{array}$ & 2 \\
\hline Kurangnya promosi pemasaran & 3 \\
\hline
\end{tabular}

Sumber: Hasil Pengolahan Data 2019

Tabel 2 Faktor-faktor Eksternal Kunci UD. Pelita Kita

\begin{tabular}{|c|c|}
\hline Faktor-faktor Internal Kunci & Skor \\
\hline \multicolumn{2}{|l|}{ Peluang: } \\
\hline 1. Meningkatnya pembuatan perumahan di kota & 4 \\
\hline Padang & 3 \\
\hline 2. Konsumen lebih memilih kayu untuk & 2 \\
\hline bangunan tahan gempa & 3 \\
\hline 3. Meningkatnya jumlah pencipta kerajinan & 2 \\
\hline kayu dari sisa-sisa hasil olahan & \\
\hline 4. Banyaknya peternak ayam yang & \\
\hline menggunakan serbuk gergaji & 3 \\
\hline 5. Banyaknya permintaan luar negeri untuk kayu & 3 \\
\hline & 2 \\
\hline Ancaman: & 2 \\
\hline $\begin{array}{l}\text { 1. Banyaknya bermunculan pesaing-pesaing } \\
\text { baru dengan konsep yang lebih modern }\end{array}$ & 1 \\
\hline 2. Keterbatasan sumder daya alam & \\
\hline Kebijakan pemerintah tentang perkayuan & \\
\hline $\begin{array}{l}\text { 4. Banyaknya kayu yang ditebang sebelum usia } \\
\text { matang }\end{array}$ & \\
\hline $\begin{array}{l}\text { 5. Banyaknya pungutan-pungutan liar yang } \\
\text { tidak resmi dari otorita tertentu }\end{array}$ & \\
\hline
\end{tabular}

Sumber: Hasil Pengolahan Data 2019

Pembuatan matriks IFE menggunakan data hasil pembobotan pada tabel 3 berikut: Tabel 3 Matriks IFE

\begin{tabular}{|c|l|l|l|}
\hline $\begin{array}{c}\text { Faktor-faktor } \\
\text { Internal }\end{array}$ & Bobot & Peringkat & $\begin{array}{l}\text { Rata-rata } \\
\text { Tertimbang }\end{array}$ \\
\hline
\end{tabular}




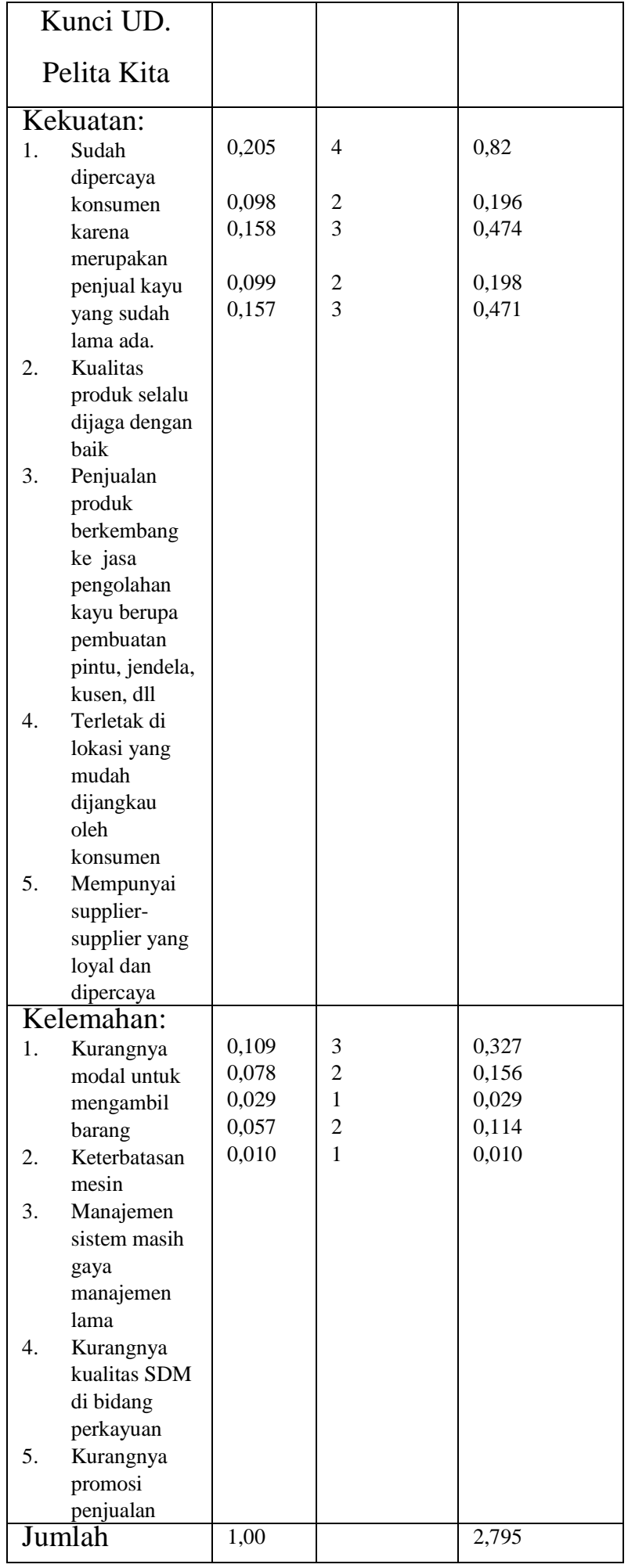

Sumber: Hasil Pengolahan Data 2019

Berdasarkan hasil dari matrik IFE di atas, diketahui bahwa faktor internal UD. Pelita Kita mempunyai nilai 2,795. Menurut David (2009) berapapun banyak faktor yang dimasukkan dalam matrik IFE, total nilai rata-rata tertimbang berkisar antara yang terendah 1,0 dan tertinggi 4,0 dengan ratarata 2,5 . Total nilai yang jauh di bawah 2,5 merupakan ciri organisasi yang lemah secara internal, sedangkantotl nilai yang jauh di atas 2,5 menunjukkan ciri organisasi yang kuat secara internal. UD. Pelita Kita dengan total nilai rata-rata tertimbang 2,795 menunjukkan bahwa strategi perusahaan dalam memanfaatkan kekuatan internal untuk meminimalkan kelemahan, berada di atas rata-rata sehingga dapat dikatakan bahwa kondisi internal perusahaan ini cenderung kuat. Pembuatan matriks EFE disajikan pada tabel 5 berikut:

\section{Tabel 5 Matriks EFE}

\begin{tabular}{|c|c|c|c|}
\hline $\begin{array}{c}\text { Faktor-faktor } \\
\text { Internal } \\
\text { Kunci UD. } \\
\text { Pelita Kita }\end{array}$ & Bobot & Peringkat & $\begin{array}{l}\text { Rata-rata } \\
\text { Tertimbang }\end{array}$ \\
\hline $\begin{array}{ll}\text { Peluang: } \\
\text { 1. } & \text { Meningkatnya } \\
& \text { pembuatan } \\
& \text { perumahan di } \\
& \text { kota Padang } \\
\text { 2. } & \text { Konsumen } \\
& \text { lebih memilih } \\
& \text { kayu untuk } \\
& \text { bangunan } \\
\text { tahan gempa } & \text { Meningkatnya } \\
\text { 3. } & \text { jumlah } \\
\text { pencipta } \\
\text { kerajinan } \\
\text { kayu dari } \\
\text { sisa-sisa hasil } \\
\text { olahan } \\
\text { Banyaknya } \\
\text { peternak } \\
\text { ayam yang } \\
\text { menggunakan } \\
\text { serbuk gergaji } \\
\text { Banyaknya } \\
\text { permintaan } \\
\text { luar negeri } \\
\text { untuk kayu }\end{array}$ & $\begin{array}{l}0,203 \\
0,127 \\
0,098 \\
0,100 \\
0,072\end{array}$ & $\begin{array}{l}4 \\
3 \\
2 \\
3 \\
3 \\
2\end{array}$ & $\begin{array}{l}0,812 \\
0,381 \\
0,196 \\
0,300 \\
0,216\end{array}$ \\
\hline
\end{tabular}




\begin{tabular}{|c|c|c|c|}
\hline $\begin{array}{ll}\text { Ancaman: } \\
\text { 1. } & \begin{array}{l}\text { Banyaknya } \\
\text { bermunculan }\end{array} \\
& \text { pesaing- } \\
\text { pesaing baru } & \text { dengan } \\
& \text { konsep yang } \\
\text { lebih modern } & \text { Keterbatasan } \\
\text { 2. } & \text { sumder daya } \\
\text { alam } & \text { Kebijakan } \\
\text { 3. } & \text { pemerintah } \\
\text { tentang } \\
\text { perkayuan } \\
\text { 4. Banyaknya } \\
\text { kayu yang } \\
\text { ditebang } \\
\text { sebelum usia } \\
\text { matang } \\
\text { Banyaknya } \\
\text { pungutan- } \\
\text { pungutan liar } \\
\text { yang tidak } \\
\text { resmi dari } \\
\text { otorita } \\
\text { tertentu }\end{array}$ & $\begin{array}{l}0,105 \\
0,120 \\
0,089 \\
0,077 \\
0,009\end{array}$ & $\begin{array}{l}3 \\
2 \\
2 \\
1\end{array}$ & $\begin{array}{l}0,315 \\
0,36 \\
0,178 \\
0,154 \\
0,009\end{array}$ \\
\hline Jumlah & 1,00 & & 2,921 \\
\hline
\end{tabular}

Sumber: Hasil Pengolahan Data 2019

Berdasarkan hasil dari hasil Matriks EFE di atas, diketahui bahwa faktor eksternal UD. Pelita Kita mempunyai nilai 2,921. Seperti pada matriks IFE, berapapun jumlah peluang dan ancaman utama yang dimasukkan dalam matriks EFE, total nilai rata-rata tertimbang berkisar antara yang terendah 1,0 dan tertinggi 4,0 dengan rata-rata 2,5. Walaupun nilai faktor eksternal UD. Pelita Kita di atas rata-rata 2,5 dan daianggab cukup baik, UD.Pelita Kita harus tetap berupaya maksimal untuk memanfaatkan peluang eksternal dan menghindari ancaman yang dapat mempengaruhi perusahaan.

Untuk mengidentifikasi pesaing-pesaing utama UD. Pelita Kita dalam posisi persaingan strategis mereka dengan kapasitas perusahaan yang sama dari semua sumber daya yang ada, maka ditetapkan dan analisisnya dapat dilihat pada tabel 6 berikut ini:

\section{Tabel 6 Matriks Kompetitif (CPM)}

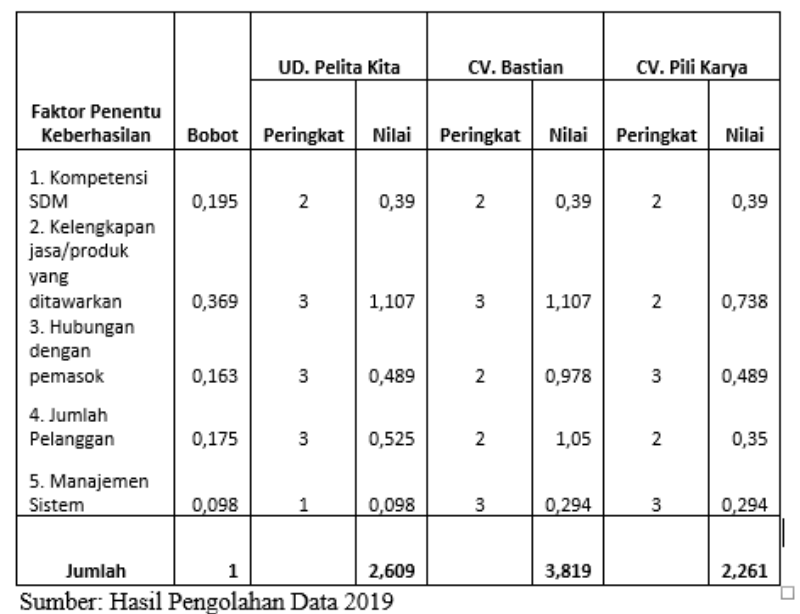

Dari hasil matrik CPM di atas, dapat diketahui bahwa total skor UD. Pelita Kita adalah 2, 609, sedangkan total skor untuk CV. Bastian adalah 3,819 dan CV. Pili Karya adalah 2,261. Hal ini menunjukkan bahwa jika dibandingkan dengan CV. Bastian, UD. Pelita Kita tidak cukup baik. Sehingga dengan CV. Bastian perusahaan harus dapat berusaha meningkatkan kapabilitas intinya yang ada dalam faktor penentu keberhasilan untuk dapat meningkatkan daya saing perusahaan dalam industri ini. Mungkin dengan meningkatkan kompetensi SDM atau merubah sistem manajemen ke arah yang lebih fleksibel (modern) sesuai dengan tuntutan perubahan. Sedangkan jika dibandingkan dengan CV. Pili Karya, UD. Pelita Kita masih cukup baik lagi.

Tahap berikutnya adalah tahap pencocokkan. Dalam tahap ini, akan digunakan beberapa metode untuk merumuskan strategi yang tepat bagi UD. Pelita Kita di dalam persaingan bisnis yang dihadapi. Metodenya antara lain Matris TOWS, Matrik SPACE, Matrik IE, dan Matriks Grand Strategi. Matriks TOWS merupakan suatu matrik yang didapatkan dari kombinasi kondisi internal dan eksternal perusahaan.Dimana ada strategi SO yang bisa didapat dengan cara memanfaatkan kekuatan perusahaan untuk mendapatkan peluang. Strategi WO yang bisa didapat perusahaan dengan meminimalisir/mensiasati kelemahan untuk tetap dapat merebut peluang yang ada. Strategi ST bisa didapat perusahaan dengan cara memanfaatkan seluruh kekuatan untuk menghadapi ancaman yang datang. Staregi WT merupakan suatu kondisi pemilihan strategi yang paling rumit karena kondisi perusahaan dihadapkan pada kelemahan internal yang ada dengan kondisi ancaman yang mesti dihadapi oleh perusahaan. Matriks TOWS dapat dilihat pada tabel 7 berikut: 
Tabel 7 Matriks Tows

\begin{tabular}{|c|c|c|}
\hline & $\begin{array}{l}\text { Kekuatan - } \mathbf{} \\
\text { 1. Dipercaya konsumen } \\
\text { 2. Kualitas produk terjaga } \\
\text { 3. Penjualan produk berkembang } \\
\text { 4. Lokasi mudah dijangkau } \\
\text { 5. Hubungan baik dengan supplier }\end{array}$ & $\begin{array}{l}\text { Kelemahan -W } \\
\text { 1. Kurangnya permodalan } \\
\text { 2. Keterbatasan mesin } \\
\text { 3. Sistem manajemen lama } \\
\text { 4. Kurangnya kualitas SDM } \\
\text { 5. Kurangnya promosi penjualan }\end{array}$ \\
\hline $\begin{array}{l}\text { Peluang - } 0 \\
\text { 1. Meningkatnya perumahan } \\
\text { 2. Kayu bangunan tahan gempa } \\
\text { 3. Meningkatnya kerajinan kayu } \\
\text { 4.Peternak ayam memakai serbuk } \\
\text { 5. Permintaan luar negri tinggi }\end{array}$ & $\begin{array}{l}\text { 1. Melakukan integrasi vertikal } \\
\text { (S1, } \mathrm{S2}, \mathrm{S3}, \mathrm{S4} ; 01,02) \\
\text { 2. Perluasan pasar }(\mathrm{S4}, 04) \\
\text { 3. Pengembangan pasar }(\mathrm{S} 2,05)\end{array}$ & $\begin{array}{l}\text { 1. Penambahan investasi }(\mathrm{W1} ; \mathrm{P1}, \mathrm{PS}) \\
\text { 2. Pengembangan SDM }(\mathrm{W} 4,05)\end{array}$ \\
\hline $\begin{array}{l}\text { Ancaman-T } \\
\text { 1. Banyaknya pesaing baru } \\
\text { 2. Keterbatasan SDA } \\
\text { 3. Kebijakan pemerintah } \\
\text { 4. Penebangan kayu usia muda } \\
\text { 5. Banyaknya pungli }\end{array}$ & $\begin{array}{l}\text { 1. Diversifikasi konsentrik (S1, } \mathrm{T} 1) \\
\text { 2. Integrasi ke hilir }(\mathrm{S5}, \mathrm{T} 2)\end{array}$ & $\begin{array}{l}\text { 1. Merger (W2, T2) } \\
\text { 2. Strategi Devensif }\end{array}$ \\
\hline
\end{tabular}

Dari hasil analisis matriks TOWS dapat diketahui bahwa dari keempat kuadran yang terbentuk dalam matriks ada empat ruangan yang bisa menjadi tempat untuk memilih strategi yang tepat yang akan digunakan oleh UD. Pelita Kita sesuai dengan kondisi real internal dan eksternal perusahaan. Dengan matriks di atas analisis penulis perusahaan bisa melakukan antara lain integrasi vertikal (ke hulu maupun ke hilir), pengembangan pasar, pengembangan SDM, merger, dan devensif. Analisis matriks SPACE dapat dilihat pada tabel 8 berikut:

\section{Tabel 8 Matriks SPACE}

\begin{tabular}{|c|c|}
\hline $\begin{array}{l}\text { KEKUATAN KEUANGAN (Finance Strength / } \\
\text { FS) = y } \\
\quad \text { Profit / laba bersih cenderung meningkat } \\
\text { - setiap tahun } \\
\text {-Pendapatan naik dari penjualan serbuk } \\
\text { dibandingkan } 2 \text { tahun lalu } \\
\quad \text { Jumlah }\end{array}$ & NILAI \\
\hline $\begin{array}{l}\text { KEKUATAN INDUSTRI (Industry Strength / } \\
\text { IS) }=\mathbf{x} \\
\text {-Potensi laba pada industri } \\
\text {-Potensi pertumbuhan yang tinggi } \\
\quad \text { Jumlah }\end{array}$ & $\begin{array}{l}4 \\
4 \\
8\end{array}$ \\
\hline $\begin{array}{l}\text { STABILITAS LINGKUNGAN (Environce } \\
\text { Strength / ES) = y } \\
\text {-Resiko bisnis yang tinggi } \\
\text {-Tingkat inflasi yang cenderung naik } \\
\quad \text { Jumlah }\end{array}$ & $\begin{array}{l}-3 \\
-2 \\
-5\end{array}$ \\
\hline 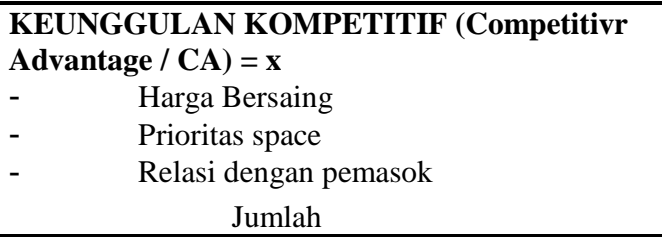 & $\begin{array}{l}-1 \\
-1 \\
-1 \\
-3\end{array}$ \\
\hline $\begin{array}{l}\text { KESIMPULAN } \\
\text { Rata-rata ES adalah }-5 \div 2=-2,5 \\
\text { Rata-rata CA adalah }-3 \div 3=-1 \\
\text { Rata-rata IS adalah } 8 \div 2=4 \\
\text { Rata-rata FS adalah } 8 \div 2=4\end{array}$ & \\
\hline
\end{tabular}

Sumbu $x(C A+I S)=-1+4=3$

Sumbu y $(E S+F S)=-2,5+4=1,5$

Sumber: Hasil Pengolahan Data 2019

Selanjutnya hasil matriks SPACE dari tabel 8 dapat digambarkan secara grafis berdasarkan hasil perhitungan yang telah didapat $(3 ; 1,5)$ sebagai berikut:

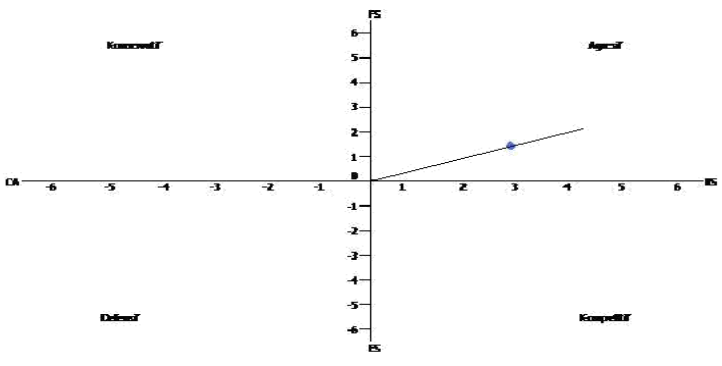

Gambar matrriks SPACE UD. Pelita Kita:

Selanjutnya dapat dilihat analisis matriks internal dan eksternal dari IFE dan EFE sebelumnya didapat bahwa hasil IFE UD. Pelita Kita 2,795 dan hasil EFE UD. Pelita Kita 2,921 (2,795 ; 2,921). Dari hasil kombinasi matriks dapat dijelaskan bahwa perusahaan berada dalam posisi yang cukup baik dalam persaingan yang ada dalam industrinya. Dalam posisi ini perusahaan tinggal mempertahankan dan memelihara posisi agar tetap stabil. Namun jika perusahaan bisa mengelola growth maka akan menambah nilai keuntungan kompetitif perusahaan dalam industri ini. Pengelolaan ini bisa dilakukan perusahaan menggunakan strategi jaga dan pertahankan; dengan penetrasi pasar dan pengembangan bentuk olahan produk.

Dari matrik IFE dan EFE didapat hasil analisis matriks Internal Eksternal sebagai berikut:

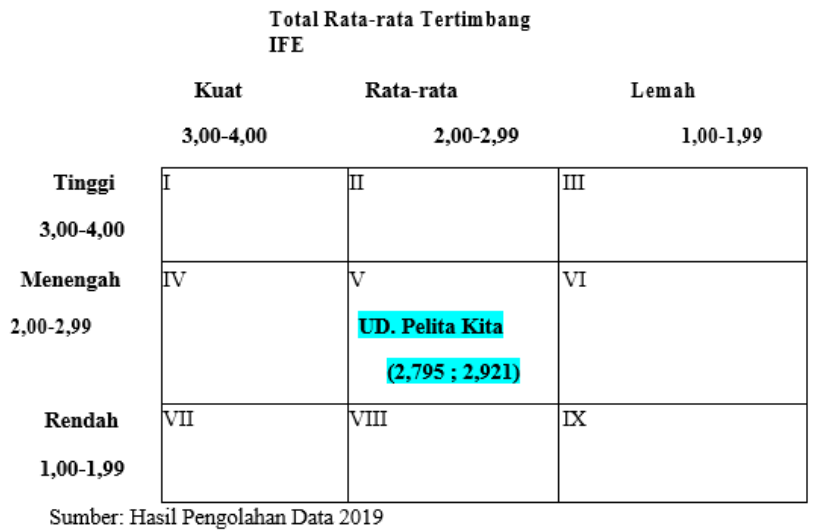

Sisi vertikal dari gambar di atas menunjukkan hasil total rata-rata tertimbang dari EFE yang 
sebelumnya sudah didapatkan. Sedangkan sisi horizontal dari gambar menunjukkan hasil total ratarata tertimbang dari IFE. Dalam hasil matrik Internal Eksternal pada gambar tersebut, UD. Pelita Kita berada pada sel nomor $\mathrm{V}$, yaitu sel pertahankan dan pelihara.Hal tersebut merupakan suatu keadaan di mana perusahaan mengalami suatu masa pertumbuhan dan dapat dikeloladengan cara terbaik menggunakan strategi jaga dan pertahankan; penetrasi pasar dan pengembangan produk adalah strategi yang umum digunakan untuk perusahaan yang masuk ke sel nomor V ini. Hasil analisis dari Matriks Grand Strategy diuraikan dalam Gambar berikut:

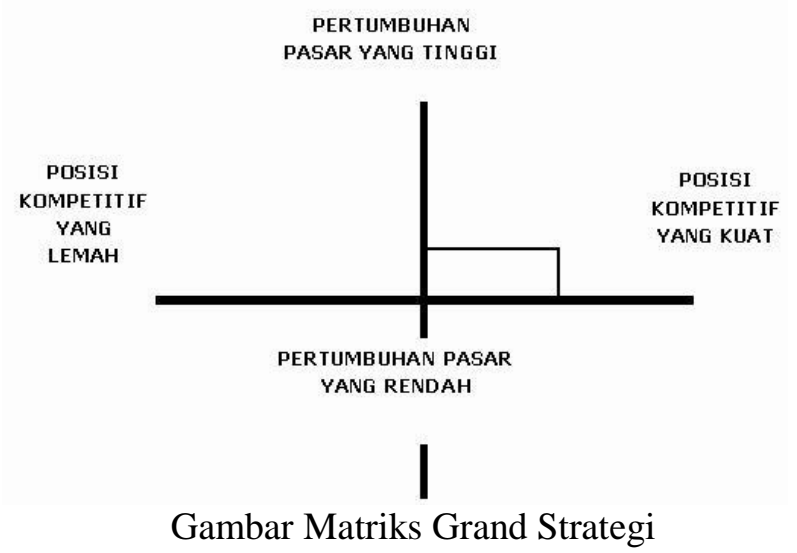

Hasil matriks grand strategi menandakan bahwa posisi yang ditempati UD. Pelita Kita merupakan kuadran I. Ini berarti bahwa secara teori beberapa pilihan strategi yang dapat diambil oleh perusahaan, yaitu penetrasi pasar, pengembangan pasar, dan pengembangan produk. Perusahaan memiliki kekuatan dan peluang yang cukup baik sehingga perusahaan dapat memanfaatkan kekuatan dan peluang tersebut untuk mengatasi kelemahan dan ancaman yang datang.

Setelah melakukan analisis dan mengetahui alternatif strategi yang muncul pada tahap analisis melalui empat macam teknik, yaitu Matriks TOWS, Matriks SPACE, Matriks Internal - Eksternal dan Matriks Grand Strategy. Langkah selanjutnya adalah membuat kesimpulan tentang alternatif strategi yang paling cocok untuk dijalankan oleh UD. Pelita Kita untuk meningkatkan daya saingnya. Dalam matriks Quantitative Strategic Planning Matrix (QSPM) yang dapat dilihat pada tabel 9 untuk faktorinternal dan tabel 10 untuk faktor eksternal, terdapat empat alternatif strategi yang dimasukkan, yaitu strategi pengembangan pasar, integrasi horizontal, pengembangan produk, dan penetrasi pasar. Keempat alternatif strategi tersebut selalu muncul dalam tahap pencocokkan.

Dalam Tabel 9, dapat dilihat bahwa total nilai daya tarik faktor internal dari strategipenetrasi pasar adalah sebesar 2,493, strategi pengembangan produk adalah sebesar 2,198, strategi integrasi vertikal/horizontal adalah sebesar 2,003, dan strategi pengembangan pasar adalah sebesar 2,237. Srategi integrasi secara vertikal bisa dilakukan ke atas maupun ke bawah. Integrasi ke atas misalnya melakukan kerjasama dengan pengguna jasa kita seperti developer, dan lain-lain (integrasi ke hulu). Integrasi ke bawah bisa dilakukan dengan menjalin kerjasama dengan pemasok (integrasi ke hilir). Sedangkan strategi integrasi horizontal bisa dilakukan perusahaan dengan cara bekerjasama dengan sesama perusahaan sejenis dalam kemampuan sumber daya yang sama pula. Untuk lebih jelasnya hasil tabel QSPM tabel 9 dapat dilihat sebagai berikut di bawah ini:

Tabel 9 Hasil QSPM Faktor Internal UD. Pelita Kita

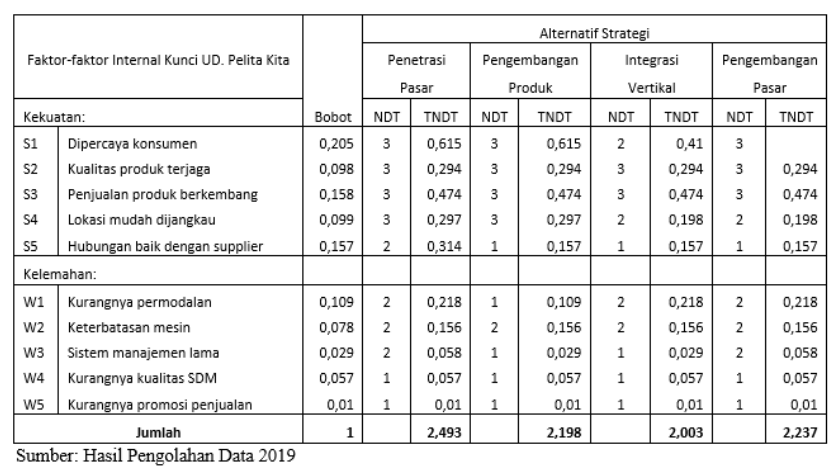

Keterangan Tabel:

NDT $=$ Nilai Daya Tarik

TNDT $=$ Total NDT

Tabel 10 Hasil QSPM Faktor Eksternal UD. Pelita Kita

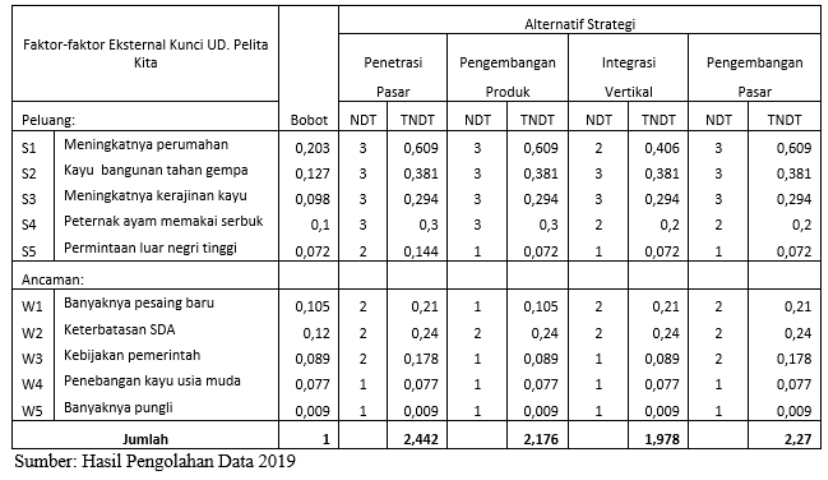

Dalam Tabel 10, dapat dilihat bahwa total nilai daya tarik faktor eksternal dari strategi penetrasi 
pasar adalah sebesar 2,442, strategi pengembangan produk adalah sebesar 2,176, strategi integrasi vertikal/horizontal adalah sebesar 1,978, dan strategi pengembangan pasar adalah sebesar 2,27. Hasil keseluruhan matriks QSPM didapat dari penjumlahan total nilai daya tarik faktor internal dan faktor eksternal yang mana dalam Tabel 11 dapat dilihat total nilai daya tarik dari keempat alternatif strategi. Dari tabel tersebut dapat dilhat strategi mana yang daya tariknya paling besar, yaitu:

\section{Tabel 11 Hasil QSPM Total Faktor Internal dan Eksternal UD. Pelita Kita}

\begin{tabular}{l|r|r|r|r|}
\hline & \multicolumn{4}{|c|}{ ALTERNATIF STRATEGI } \\
\cline { 2 - 5 } & $\begin{array}{c}\text { Penetrasi } \\
\text { Pasar }\end{array}$ & $\begin{array}{c}\text { Pengembangan } \\
\text { Produk }\end{array}$ & $\begin{array}{c}\text { Integrasi } \\
\text { V/H }\end{array}$ & $\begin{array}{c}\text { Pengembangan } \\
\text { Pasar }\end{array}$ \\
\hline $\begin{array}{l}\text { QSPM } \\
\text { FAKTOR } \\
\text { INTERNAL }\end{array}$ & 2,493 & 2,198 & 2,003 & 2,237 \\
\hline $\begin{array}{l}\text { QSPM } \\
\text { FAKTOR } \\
\text { EKSTERNAL }\end{array}$ & 2,422 & 2,176 & 1,978 & 2,27 \\
\hline TOTAL & 4,915 & 4,374 & $\mathbf{3 , 9 8 1}$ & 4,507 \\
\hline
\end{tabular}
Sumber: Hasil Pengolahan Data 2019

Dari Tabel 11, terlihat bahwa dari empat alternatif strategi, jika diurutkan dari total nilai daya tarik terbesar, maka strategi penetrasi pasar adalah urutan teratas dengan total nilai daya tarik 4,915, artinya strategi ini paling baik digunakan oleh UD. Pelita Kita dalam menghadapi persaingan. Terbaik ke dua adalah strategi pengembangan pasar dengan total nilai daya tarik $\mathbf{4 , 5 0 7}$. Strategi pengembangan produk adalah alternatif ke tiga yang bisa dijadikan pilihan dengan total nilai daya tarik $\mathbf{4 , 3 7 4}$, dan urutan terakhir dari strategi yang bisa digunakan perusahaan adalah strategi vertikal/horizontal dengan total nilai daya tarik 3,981 .

\section{KESIMPULAN DAN SARAN}

Kekuatan utama UD. Pelita Kita untuk tetap dapat mempertahankan sustainability terletak pada kepercayaan konsumen dari kualitas produk yang selalu baik dan telah dibuktikan oleh konsumen dari waktu ke waktu. Hal ini dapat dilihat dengan mampunya perusahaan bertahan sejak tahun berdirinya di tahun 1970-an sampai sekarang ini. Kekonsistetan perusahaan mempertahankan kualitas produk yang mereka jual dan mereka proses selalu terjaga. Lokasi yang strategis membuat akses konsumen untuk menjangkau perusahaan sangat mudah. Dan perusahaan mampu mengembangkan jenis produk/jasa mereka. Tidak hanya menjual dan mengolah produk kayu dalam bentuk ukuran pembelahan dan pengetaman saja. Tapi berkembang ke pengolahan pembuatan les profil, pembuatan pintu, kunsen, jendela, tongkat pramuka, jelusi, dan lain-lain. Dengan demikian pengembangan jenis produk/jasa yang telah dilakukan oleh perusahaan dan perluasan pasar dengan menjangkau segmen lain serta pemanfaatan nilai ekonomis dari serbuk hasil olahyang semula hanya sebatas limbah saja, merupakan suatu hal yang sangat sejalan dengan strategi penetrasi pasar (geliat pasar) yang dianjurkan untuk perusahaan dari hasil penulisan artikel ini.

\section{REFERENSI}

[1] David, F. R. (2009). Strategic management, $12^{\text {th }}$ ed., New Jersey: Pearson Prentice Hall.

[2] Grant, R. M. (1991). The resource base theory of competitive advantage, California dalam JournalManagement Review, (2010); 33 (3), 114-135.

[3] Hitt, Michael A, et al. (2001). Strategic management-competitiveness and globalization, $4^{\text {th }}$ ed., United States of America: Thomson Learning.

[4] Kaplan and Norton. (2008). The execution premium: Linking strategy to operation for competitive, Boston: Harvard Business School Publishing Corporation.

[5] Kuncoro, Engkos Ahmad. (2010). Analisis Perumusan Strategi Bisnis Pada PT. Samudera Nusantara Logistindo. Dalam Jurnal BINUS BUSINESS REVIEW, Vol. 1 No. 1, 169 -184, Mei 2010.

[6] Lindelof, P., and Hans Lofsten. (2004). Proximity as a resource base for competitive advantage:university-industry links for technology transfer. Dalam Journal of Technology Transfer, 29, 3-4, (Online), August 2009.

[7] Porter, M. E. (1998). On competition, Boston : Harvard Business School Publishing Corporation.

[8] Rangkuti, F. (1998). Analisis SWOT teknik membedah kasus bisnis, Jakarta: PT Gramedia.

[9] Sugiono. (2003). Metode penelitian bisnis, cetakan pertama, Bandung: Alfabeta.

[10] Tafti, Jalili, Yaeian. (2013). Assesment and Analysis Stretegies According to Space MatrixCase Study: Petrocemical and Banking Industries in Tehran Stock Exchange (TSE). In 
Journal Procedia-Social and Behavioral Science 99, 893-901, 2013.

[11] Walker, G. (2007). Modern competitive strategy, $2^{\text {nd }}$ ed., New York: The Mc.Graw Hill Companies,Inc.

[12] Wheelen, T. L., and Hunger J. D. (2001). Strategic management and business policy, $5^{\text {th }}$ ed., United States of America: AddisonWesley Publishing Company.

[13] Yuwono, S., dan Ichsan. (2007). Petunjuk praktis penyusunan Balanced Scorecard, menuju organisasiyang berfokus pada srategi, cetakan kelima, Jakarta: PT Gramedia Pustaka Utama. 